\title{
Hypercapnia Attenuates the Hypoxia-Induced Blunting of the Reactivity in Chronically Hypoxic Rats
}

\author{
M. ŽALOUDÍKOVÁ ${ }^{1}$, J. HERGET ${ }^{2}$, M. VÍZEK ${ }^{1}$ \\ ${ }^{1}$ Department of Pathophysiology, Second Faculty of Medicine, Charles University, Prague, Czech \\ Republic, ${ }^{2}$ Department of Physiology, Second Faculty of Medicine, Charles University, Prague, \\ Czech Republic
}

Received May 13, 2013

Accepted July 10, 2013

On-line July 17, 2013

\section{Summary}

Chronic hypoxia causes oxidative injury of pulmonary vessels and attenuates their reactivity to different stimuli. When combined with hypercapnia, biochemical markers of this injury are reduced but the effect of concomitant hypoxia and hypercapnia on vascular reactivity is not fully understood. This study was therefore designed to test whether hypercapnia can prevent also the hypoxia-induced loss of reactivity of pulmonary vessels. The reactivity of vessels from rats exposed either to hypoxia or hypoxia combined with hypercapnia was tested using a small vessel myograph (M 500A, Linton, Norfolk, GB). The second and third intrapulmonary branches of pulmonary arteries were isolated under a dissecting microscope from lungs of 8 control rats (group $\mathrm{N}$ ), 6 rats exposed to hypoxia for 5 days (isobaric, $10 \% \mathrm{O}_{2}$, group $\mathrm{H}$ ) and 7 rats exposed to hypoxia combined with hypercapnia for 5 days $\left(10 \% \mathrm{O}_{2}, 5 \% \mathrm{CO}_{2}\right.$, group $\left.\mathrm{H}+\mathrm{CO}_{2}\right)$. The transmural pressure was set by automatic normalization to $30 \mathrm{~mm} \mathrm{Hg}$. The vessel size did not vary among the groups. After stabilization we challenged the vessels twice with $\mathrm{KCl}(80 \mathrm{mM})$ and once with $\mathrm{PGF}_{2 \alpha}(0.1 \mathrm{mM})$. There were no significant differences in $\mathrm{KCl}$ induced contractions among the groups. The responses to $\mathrm{PGF}_{2 \alpha}$ were expressed as a ratio to the maximal tension obtained by the exposure to $80 \mathrm{mM} \mathrm{KCl}$. Contractions induced by $\mathrm{PGF}_{2 \alpha}$ were markedly reduced in group $\mathrm{H}(0.07 \pm 0.02)$ and in group $\mathrm{H}+\mathrm{CO}_{2}(0.26 \pm 0.03)$ in comparison with group $\mathrm{N}$ $(0.83 \pm 0.07)$. The vessels of group $\mathrm{H}$ responded to $\mathrm{PGF}_{2 \alpha}$ less than those of group $\mathrm{H}+\mathrm{CO}_{2}$. However we observed the attenuated reactivity also in group $\mathrm{H}+\mathrm{CO}_{2}$ in comparison with $\mathrm{N}$. Hypercapnia therefore partially blunted the hypoxia-induced loss of reactivity in pulmonary arteries. This finding supports the hypothesis that hypercapnia significantly alters the nature of lung injury induced by chronic hypoxia.

\section{Key words}

Isolated pulmonary arteries • Hypoxia • Hypercapnia

\section{Corresponding author}

M. Žaloudíková, Department of Pathophysiology, Second Faculty of Medicine, Charles University, Plzeňská 221, 15000 Prague, Czech Republic. E-mail: marie.zaloudikova@lfmotol.cuni.cz

Sustained alveolar hypoxia increases the resistance of pulmonary vessels resulting in hypoxic pulmonary hypertension (HPH). The resistance increases because of remodelling of pulmonary vessels and their vasoconstriction (Reid 1986). In some experiments, hypercapnia partially inhibited the development of $\mathrm{HPH}$ (Ooi et al. 2000, Herget et al. 2001, 2002, Howell et al. 2004, Kantores et al. 2006). While it has been recently shown that the process of remodelling is less pronounced when hypoxia combines with hypercapnia (Veselá and Wilhelm 2002, Chovanec et al. 2009), the effect of combined hypoxia and hypercapnia on the reactivity of pulmonary vessels remains, as far as we know, not fully understood. Elucidation of this effect has clinical implications: constriction of pulmonary vessels diverts the blood flow from hypoventilated areas and the blunting of this response results in a ventilation/perfusion mismatch. In in vitro experiments, the initial phases of 
exposure to chronic hypoxia are characterised by the blunting of the isolated pulmonary vascular reactivity (McMurtry et al. 1978, Reeve et al. 2001). We hypothesize that exposure of animals to hypoxia with concomitant hypercapnia could protect also the pulmonary vascular responsiveness. Therefore we tested the response of isolated small pulmonary arteries from rats exposed to either chronic hypoxia or chronic hypoxia combined with hypercapnia.

Experiments on adult male Wistar rats were performed in accordance with the European Community and NIH guidelines for using experimental animals. All procedures were approved by our institution's Animal Studies Committee. The mean body weight of animals was $279 \pm 41 \mathrm{~g}$ and did not vary among the groups. The first group (group $\mathrm{H}, \mathrm{n}=6$ ) was exposed to chronic hypoxia for 5 days in an isobaric hypoxic chamber $\left(\mathrm{FiO}_{2}=0.1\right) \cdot \mathrm{CO}_{2}$ was completely reabsorbed in a closed circuit by KOH and soda lime (Hampl and Herget 1990). In the second group $\left(\mathrm{H}+\mathrm{CO}_{2}, \mathrm{n}=7\right)$, rats were exposed to hypoxia $\left(\mathrm{FiO}_{2}=0.1\right)$ and hypercapnia $\left(\mathrm{FiCO}_{2}=0.04-0.05\right)$ for 5 days. The increase in carbon dioxide concentration was achieved by bypassing the $\mathrm{KOH}$ absorber. The concentration of $\mathrm{CO}_{2}$ was continuously monitored. The third group of rats $(\mathrm{N}, \mathrm{n}=8)$ lived in atmospheric air. After 5 days of exposure the rats were sacrificed using an intraperitoneal injection of thiopental.

Measurements of pulmonary arterial vasoconstriction were performed on stretched isolated vessel rings using a small vessel myograph (M 500A, Linton, Norfolk, GB). To obtain the rings, we excised the lungs en bloc and placed them in cold physiological salt solution (PSS, $\mathrm{NaCl} 6.954 \mathrm{~g} / 1, \quad \mathrm{KCl} \quad 0.35 \mathrm{~g} / 1$,

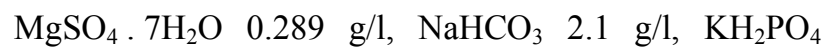
$0.161 \mathrm{~g} / 1$, glucose $\left.1.091 \mathrm{~g} / 1, \mathrm{CaCl}_{2} \cdot 2 \mathrm{H}_{2} \mathrm{O} \quad 0.368 \mathrm{~g} / \mathrm{l}\right)$. Small pulmonary arteries (SPA, 250-550 $\mu$ m i.d.) were dissected free of adventitia and mounted in the myograph. The temperature in the chamber was set at $37^{\circ} \mathrm{C}$ and the solution was gassed continuously with $95 \% \mathrm{O}_{2}+5 \% \mathrm{CO}_{2}$ (pH 7.4). After $30 \mathrm{~min}$ of stabilization the arteries were stretched to give an equivalent transmural pressure of $30 \mathrm{~mm} \mathrm{Hg}$ (Leach et al. 1992).

At the start of each experiment, vessels were exposed to $80 \mathrm{mM} \mathrm{K}^{+}$to reach a maximal contractile response. $\mathrm{K}^{+}$-rich solution was obtained by replacing an equimolar amount of $\mathrm{KCl}$ for $\mathrm{NaCl}$ in PSS (KPSS). This maximal contraction served as a reference response and was used to normalize subsequent contractile responses. Resting tension remained unchanged throughout the

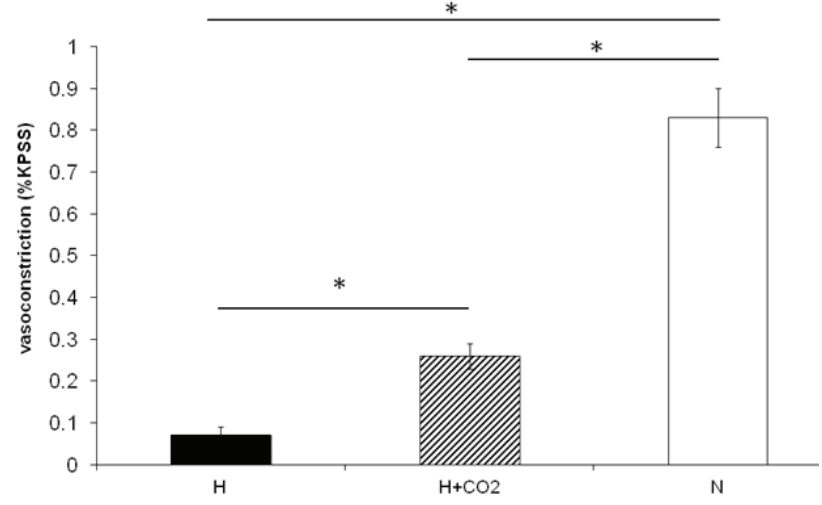

Fig. 1. The contractile responses of isolated pulmonary arteries (means \pm SEM) to the administration of $0.1 \mathrm{mM} \mathrm{PGF}_{2 \mathrm{a}}$ expressed as a ratio to the maximal tension obtained by the exposure to $80 \mathrm{mM} \mathrm{KCl}$ (KPSS) in each vessel ring. $\mathrm{H}$ - rats exposed to chronic hypoxia, $\mathrm{H}+\mathrm{CO}_{2}$ - rats exposed to hypoxia combined with hypercapnia, $\mathrm{N}-$ control normoxic rats, $*-\mathrm{P} \leq 0.05$. Chronic hypoxia combined with hypercapnia attenuated the contractile responses of small pulmonary arteries less than hypoxia alone.

experimental period. Then we stimulated vessel rings using $0.1 \mathrm{mM} \quad \mathrm{PGF}_{2 \alpha} . \mathrm{PGF}_{2 \alpha}$ is the widely used vasoconstrictor affecting both the $\mathrm{Ca}^{2+}$ sensitivity and the $\mathrm{Ca}^{2+}$ influx (Snetkov et al. 2006).

At the maximum of the contractile response we induced the step-wise relaxation of SPA by the administration of acetylcholine (ACHe) in concentrations of $10^{-6}, 10^{-5}, 10^{-3} \mathrm{M}$. The concentration of acetylcholine in the bath was stepped up always after reaching the plateau of tension. The KPSS induced contraction was repeated at the end of each experiment to prove the viability of pulmonary arterial rings throughout the experiment. The statistical evaluation was performed using ANOVA and Fisher's post-hoc test with the significance $\mathrm{p} \leq 0.05$.

The maximal tension induced by KPSS did not significantly differ among the groups of vessel rings. Thus neither hypoxia nor hypoxia combined with hypercapnia affected the maximal contractile response of pulmonary vessels. The contractile responses to the administration of $0.1 \mathrm{mM} \mathrm{PGF}_{2 \alpha}$ are shown in Figure 1. The results are expressed as the ratio of the $\mathrm{PGF}_{2 \alpha}$ stimulated contraction to the maximal response of each vessel induced by KPSS. Both groups exposed to hypoxia responded to $\mathrm{PGF}_{2 \alpha}$ less than controls but the tension developed by vessel rings from rats exposed to hypoxia and hypercapnia was significantly higher than that of rings from animals exposed to only hypoxia. Thus the hypercapnia partly prevented the inhibition of the pulmonary arterial reactivity induced by exposure to chronic hypoxia. The administration of acetylcholine in a 
concentration of $10^{-3} \mathrm{M}$ returned the vascular tension to the baseline level in all three groups.

The main finding of this report is that hypercapnia attenuates the hypoxia-induced blunting of the reactivity of small pulmonary vessels. Chronic hypoxia has been shown to reduce or block the response of pulmonary vessels to the different stimuli including acute hypoxia or $\mathrm{PGF}_{2 \alpha}$ (McMurtry et al. 1978, Reeve et al. 2001). This decreased reactivity was attributed to radical injury of vascular tissue (Hampl and Herget 1991, Herget et al. 2000). Hypoxia induced formation of reactive oxygen species (Perez-Vizcaino et al. 2010) has been shown to increase $\mathrm{Ca}^{2+}$ influx into the vascular smooth muscle cells (Archer and Michelakis 2002) as well as the sensitivity of contractile apparatus to $\mathrm{Ca}^{2+}$ (Bonnet et al. 2001). Therefore the increased initial vascular tension (Broughton et al. 2008) seems acceptable explanation. The fact that we did not find any difference in responses to $\mathrm{KCl}$ stimulation suggested that chronic hypoxia or the hypoxia combined with hypercapnia did not change the ability of contractile elements to contract. Thus the hypoxia likely affected the mechanism controlling the contraction. The effect of hypercapnia could be explained by its scavenging activity (Shibata et al. 1998, Laffey et al. 2000, Skoumalová et al. 2008, Chovanec et al. 2009). However, although stepwise relaxation of all vessel rings by ACHe, which is used as a test of endothelial dysfunction (Furchgott and Zawadzki 1980), excludes serious damage of endothelial cells, the participation of endothelial cells in the changed vascular reactivity cannot be ruled out. In conclusion, our data shows that relatively mild hypercapnia has a protective effect on hypoxia induced changes of vessel reactivity.

\section{Conflict of Interest}

There is no conflict of interest.

\section{Acknowledgements}

This study was partially supported by grants IGA NT 13358-4, GAČR 13-01710S.

\section{References}

ARCHER S, MICHELAKIS E: The mechanism(s) of hypoxic pulmonary vasoconstriction: potassium channels, redox $\mathrm{O}(2)$ sensors, and controversies. News Physiol Sci 17: 131-137, 2002.

BONNET S, BELUS A, HYVELIN JM, ROUX E, MARTHAN R, SAVINEAU JP: Effect of chronic hypoxia on agonist-induced tone and calcium signaling in rat pulmonary artery. Am J Physiol Lung Cell Mol Physiol 281: L193-L201, 2001.

BROUGHTON BR, WALKER BR, RESTA TC: Chronic hypoxia induces Rho kinase-dependent myogenic tone in small pulmonary arteries. Am J Physiol Lung Cell Mol Physiol 294: L797-L806, 2008.

FURCHGOTT RF, ZAWADZKI JV: The obligatory role of endothelial cells in the relaxation of arterial smooth muscle by acetylcholine. Nature 288: 373-376, 1980.

HAMPL V, HERGET J: Perinatal hypoxia increases hypoxic pulmonary vasoconstriction in adult rats recovering from chronic exposure to hypoxia. Am Rev Respir Dis 142: 619-624, 1990.

HAMPL V, HERGET J: Possible mechanisms of oxygen sensing in the pulmonary circulation. Physiol Res 40: 463-470, 1991.

HERGET J, NOVOTNÁ J, BLÁHOVÁ L: Effect of hypercapnia on vascular remodelling induced by chronic hypoxia. Physiol Res 51: 12P, 2002.

HERGET J, VYTÁŠEK R, BAŇASOVÁ A, BÍBOVÁ J, HAMPL V, FIŠÁRKOVÁ B: Hypercapnia inhibits hypoxic pulmonary hypertension in rats. Physiol Res 50: P7, 2001.

HERGET J, WILHELM J, NOVOTNÁ J, ECKHARDT A, VYTÁŠEK R, MRÁZKOVÁ L, OŠŤÁDAL M: A possible role of the oxidant tissue injury in the development of hypoxic pulmonary hypertension. Physiol Res 49: 493-501, 2000.

HOWELL K, OOI H, PRESTON R, MCLOUGHLIN P: Structural basis of hypoxic pulmonary hypertension: the modifying effect of chronic hypercapnia. Exp Physiol 89: 66-72, 2004.

CHOVANEC M, NOVOTNÁ J, WILHELM J, HAMPL V, VÍZEK M, HERGET J: Hypercapnia attenuates hypoxic pulmonary hypertension by inhibiting lung radical injury. Physiol Res 58: S79-S85, 2009. 
KANTORES C, MCNAMARA PJ, TEIXEIRA L, ENGELBERTS D, MURTHY P, KAVANAGH BP, JANKOV RP: Therapeutic hypercapnia prevents chronic hypoxia-induced pulmonary hypertension in the newborn rat. $A m J$ Physiol Lung Cell Mol Physiol 291: L912-L922, 2006.

LAFFEY JG, TANAKA M, ENGELBERTS D, LUO X, YUAN S, TANSWELL AK, POST M, LINDSAY T, KAVANAGH BP: Therapeutic hypercapnia reduces pulmonary and systemic injury following in vivo lung reperfusion. Am J Respir Crit Care Med 162: 2287-2294, 2000.

LEACH RM, TWORT CH, CAMERON IR, WARD JP: A comparison of the pharmacological and mechanical properties in vitro of large and small pulmonary arteries of the rat. Clin Sci (Lond) 82: 55-62, 1992.

MCMURTRY IF, PETRUN MD, REEVES JT: Lungs from chronically hypoxic rats have decreased pressor response to acute hypoxia. Am J Physiol 235: H104-H109, 1978.

OOI H, CADOGAN E, SWEENEY M, HOWELL K, O'REGAN RG, MCLOUGHLIN P: Chronic hypercapnia inhibits hypoxic pulmonary vascular remodeling. Am J Physiol Heart Circ Physiol 278: H331-H338, 2000.

PEREZ-VIZCAINO F, COGOLLUDO A, MORENO L: Reactive oxygen species signaling in pulmonary vascular smooth muscle. Respir Physiol Neurobiol 174: 212-220, 2010.

REEVE HL, MICHELAKIS E, NELSON DP, WEIR EK, ARCHER SL: Alterations in a redox oxygen sensing mechanism in chronic hypoxia. J Appl Physiol 90: 2249-2256, 2001.

REID LM: Structure and function in pulmonary hypertension. New perceptions. Chest 89: 279-288, 1986.

SHIBATA K, CREGG N, ENGELBERTS D, TAKEUCHI A, FEDORKO L, KAVANAGH BP: Hypercapnic acidosis may attenuate acute lung injury by inhibition of endogenous xanthine oxidase. Am J Respir Crit Care Med 158: 1578-1584, 1998.

SKOUMALOVÁ A, HERGET J, WILHELM J: Hypercapnia protects erythrocytes against free radical damage induced by hypoxia in exposed rats. Cell Biochem Funct 26: 801-807, 2008.

SNETKOV VA, KNOCK GA, BAXTER L, THOMAS GD, WARD JP, AARONSON PI: Mechanisms of the prostaglandin F2alpha-induced rise in [Ca2+]i in rat intrapulmonary arteries. $J$ Physiol 571: 147-163, 2006.

VESELÁ A, WILHELM J: The role of carbon dioxide in free radical reactions of the organism. Physiol Res 51: 335-339, 2002. 